\title{
麻配科医からみた周術期輸液療法の考え方
}

Anesthesiologist's Perioperative Fluid Management

Strategies

\section{辛島 裕士}

Yuji Karashima

九州大学大学院医学研究院麻酔・蘇生学

Kyushu University, Graduate School of Medical Sciences, Department of Anesthesiology \& Critical Care Medicine

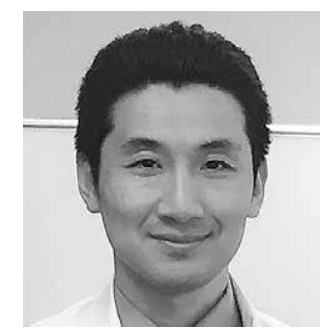

周術期輸液療法の目的、特に術中輸液・輸血の大きな目的の一つは、酸素需給バランスを目指した前 負荷の維持である。適切な前負荷を維持することで血圧が維持され、組織灌流が維持され、組織への酸 素供給が維持される。手術侵襲が加わると炎症が惹起され浮腫が形成され、血管内用量を保持しにくい 状況が生まれる。そのため周術期輸液療法では、いかにして水分を血管内に留めるか、そしてどうすれ ば間質浮腫を最小限に抑えることが可能か、を考えながら前負荷の維持に努める必要がある。しかし、 その重要性が認識されているにもかかわらず、いまだ我々は至適輸液療法を模索している状態である。 術中の輸液療法の考え方には変遷があり、晶質液を大量に輸液する方法から、逆に輸液を必要最小限に 絞る制限輸液療法の考え方を経て、現在では「輸液最適化」の考え方が主流となっている。そして、そ の輸液最適化を目指すべく目標指向型輸液療法 [Goal-directed fluid therapy（GDFT) ] が提唱された。 GDFT では制限的晶質液投与と必要時の膠質液急速投与が 2 つの大きな柱となる。そして術中に用い る膠質液はアルブミン製剤ではなく人工膠質液が第一選択となる。この人工膠質液は主に術中に用いら れ、術後に用いられることはほとんどない。そこで本シンポジウムでは、麻酔科医以外にとっては未だ 馴染みの薄い人工膠質液について紹介するとともに、GDFTを中心に現在の麻酔科医からみた術中輸 液の考え方を概説する。周術期にかかわるすべてのスタッフと情報を共有することで、より良い周術期 の輸液療法の確立を目指していければと考えている。 